\title{
Einer für alles: Der DRG-Mitglieder-LogIn
}

Teilnahmebescheinigungen herunterladen, persönlichen Daten ändern, Rechnungen einsehen: in Ihrem DRG-Mitgliederbereich auf drg.de > DRG LOGIN stehen Ihnen eine Reihe nützlicher Funktionen zur Verfügung.

Sie können beispielsweise mit conrad lernen, der interaktiven Lehrplattform der DRG, sich in den Vortragsbereich der Akademie für Fort- und Weiterbildung in der Radiologie einloggen oder aber ein individuelles Suchprofil im Veranstaltungskalender anlegen.

Wenn Sie Mitglied sind, aber noch keinen Zugang haben, folgend Sie einfach der Anleitung unter dem Stichwort „Passwort vergessen“.

Mehr Informationen finden Sie auf drg.de $>$ DRG LOGIN

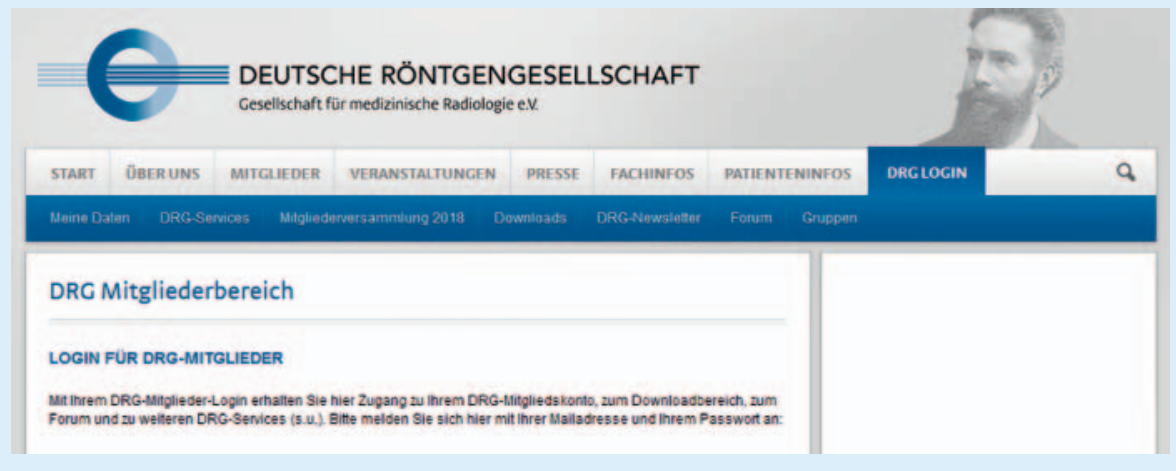

